JKM (Jurnal Kebidanan Malahayati),Vol 7,No.4.Oktober 2021,

ISSN (Print) 2476-8944 ISSN (Online) 2579-762X, Hal 793-800

\title{
PENGARUH KONSUMSI JAMBU BIJI TERHADAP KADAR HB PADA IBU HAMIL ANEMIA
}

\author{
Ani Mustika ${ }^{1}$, Anggraini $^{2}$, Ledy Octaviani lqmy ${ }^{3}$, Rosmiyati $^{4}$ \\ 1,2Prodi DIV Kebidanan Universitas Malahayati Bandar Lampung \\ ${ }^{3}$ Prodi DIII Kebidanan Universitas Malahayati Bandar Lampung \\ *Korespondensi email : anggraini@malahayati.ac.id
}

\section{THE EFFECT OF GUARANTEE CONSUMPTION ON HB LEVELS IN ANEMIA PREGNANT WOMEN IN BPM OKDIAH BETTY, TRIMURJO DISTRICT, CENTRAL LAMPUNG DISTRICT}

Background : Data on visits of pregnant women who perform Antenatal Care (ANC) at BPM Okdiah Betty Kec. Trimurjo Kab. Lampung Tengan from December 2020 to January 2021, as many as 59 people. Based on the results of a pre-survey conducted at BPM Okdiah Betty, Amd. Keb Kec. Trimurjo Kab. Central Lampung in January 2021, there were 59 pregnant women in the I-III trimester who made ANC visits in December 2020 to January 2021. The purpose : of this research is to prove the effect of guava consumption (Psidium Guajava L) on hemoglobin levels in anemic pregnant women.

Method :The type of research is quantitative, research design methods Experiment withapproach. twogroup pretest posttest. Data on visits from pregnant women at BPM Okdiah Betty, Trimurjo District, Central Lampung Regency, obtained the number of pregnant women TM I-III from December 2020 to January 2021 as many as 59 people, purposive sampling technique was used, univariate and bivariate data analysis using t-test.

Result : The average HB levels in pregnant women before being given guava and Fe tablets with a mean of $10,533 \mathrm{~g} / \mathrm{dlth}$ min value is $9.00 \mathrm{gr} / \mathrm{dl}$ and the max value is $11.40 \mathrm{gr} / \mathrm{dl}$. The average $\mathrm{Hb}$ level after being given guava and fe tablets with a mean of $11.580 \mathrm{gr} / \mathrm{dlm}$ min value $11.50 \mathrm{gr} / \mathrm{dl}$ and max value $11.80 \mathrm{gr} / \mathrm{dl}$, the results of statistical tests obtained $P$-value $=0.000(<0.05)$.

Conclusion : which means that there is an effect of guava consumption on $\mathrm{Hb}$ levels in anemic pregnant women.There is an effect of guava consumption on $\mathrm{Hb}$ levels in anemic pregnant women at BPM Okdiah Betty, Trimurjo District, Central Lampung Regency.As information material for respondents that consuming guava can increase hemoglobin levels in pregnant women so as to prevent anemia in pregnant women

Suggestion it is hoped that pregnant women will eat guava as a food choice that contains high vitamin $C$ which can increase $\mathrm{Fe}$ absorption in pregnant women. so that the absorption of $\mathrm{Fe}$ can be maximized so that anemia does not occur.

Key words : Guava, Hb Levels, Anemia Pregnant Women

\section{ABSTRAK}

Latar belakang :Data kunjungan ibu hamil yang melakukan Antenatal Care (ANC) di BPM Okdiah Betty Kec. Trimurjo Kab. Lampung Tengan sejak bulan desember 2020 sampai dengan januari 2021 yaitu sebanyak 59 orang. Berdasarkan hasil pre survey yang peneliti lakukan di BPM Okdiah Betty,Amd.Keb Kec.Trimurjo Kab.Lampung Tengah pada bulan Januari 2021 terdapat 59 ibu hamil trimester I-III yang melakukan kunjungan ANC pada bulan Desemder 2020 hingga Januari 2021.Tujuan penlitian ini adalah diketahuipengaruh konsumsi jambu biji (Psidium Guajava L) terhadap kadar hemoglobin pada ibu hamil anemia.

Metode:Jenis penelitian kuantitatif, rancangan penelitian metode Eksperiment dengan pendekatan two group pretest posttest. Data Kunjungan ibu hamil di BPM Okdiah Betty Kecamatan Trimurjo Kabupaten Lampung Tengah, didapat jumlah ibu hamil TM I-III sejak bulan desember 2020 sampai dengan januari 2021 sebanyak 59 orang, teknikpengambilan sampel purposive sampling., analisa data univariat dan bivariat menggunakan t-test.

Hasil :Rata-rata kadar HB pada ibu hamilsebelum diberi jambu biji dan tablet $\mathrm{Fe}$ dengan Mean10,533gr/dnilai min $9,00 \mathrm{gr} / \mathrm{dl}$ dan nilai max 11,40gr/dl.Rata-rata kadar $\mathrm{Hb}$ setelah diberi jambu biji dan tablet fe dengan Mean11,580 gr/dlnilai min $11,50 \mathrm{gr} / \mathrm{dl}$ dan nilai max 11,80 gr/dl,Hasil uji statistik didapatkan nilai $P$-value $=0.000(<0,05)$ yang artinya terdapat pengaruh konsumsi jambu biji terhadap kadar $\mathrm{Hb}$ pada ibu hamil anemia.

Kesimpulan :Terdapat pengaruh konsumsi jambu biji terhadap kadar Hb pada ibu hamil anemia di BPM Okdiah Betty Kecamatan Trimurjo Kabupaten Lampung Tengah. Sebagai bahan informasi bagi responden bahwa 
dengan mengonsumsi jambu biji dapat meningkatkan kadar hemoglobin pada ibu hamil sehingga dapat mencegah terjadinya anemia pada ibu hamil

Saran diharapkan ibu hamil mau mengonsumsi jambu biji sebagai pilihan makanan yang mengandung vitamin $\mathrm{C}$ tinggi yang dapat meningkatkan absorpsi Fe pada ibu hamil sehingga absorpsi Fe dapat maksimal sehingga tidak terjadi anemia.

Kata Kunci : Jambu Biji, Kadar Hb, Ibu Hamil Anemia

\section{PENDAHULUAN}

Anemia yang terjadi pada kehamilan adalah karena kekurangan zat besi, dan merupakan jenis anemia yang pengobatannya dapat dilakukan dengan mudah dan murah. Pada pengamatan lebih lanjut menunjukkan bahwa mayoritas anemia yang diderita masyarakat adalah karena kekurangan zat besi yang dapat diatasi melalui pemberian zat besi secara teratur dan peningkatan zat gizi. (Manuaba, 2010).

Menurut World Healt Organization (WHO) tahun 2018 lebih dari 40\% ibu hamil yang ada di dunia mengalami anemia. Sebanyak 35\%-75\% ibu hamil di negara berkembang dan $18 \%$ di negara industry mengalami anemia. Di Asia kasus ibu hamil anemia masih tinggi yaitu sekitar $60 \%$. Berdasarkan Riset Kesehatan Dasar (Riskesdas) tahun 2018 ibu hamil yang mengalami anemia meningkat yaitu sebanyak 48,9\% sedangkan pada tahun 2013 sebanyak $37,1 \%$. Angka kejadian anemia di Provinsi Lampung pada tahun 2017 sebanyak 2.294 orang. (Dinas Kesehatan Provinsi Lampung, 2017). Sedangkan di Kabupaten Lampung Tengah tercatat bahwa kejadian anemia pada ibu hamil yaitu $15,39 \%$.

Kategori kadar hemoglobin pada wanita hamil adalah normal $11 \mathrm{gr} / \mathrm{dl}$, anemia ringan 8 sampai $<11 \mathrm{gr} / \mathrm{dl}$, anemia sedang 6 sampai 7,9 $\mathrm{gr} / \mathrm{dl}$, nemia berat (<6 gr/dl). (Ani, 2010).

Anemia pada ibu hamil dapat dicegah dengan cara meningkatkan konsumsi makanan yang bergizi seimbang, seperti makanan yang banyak mengandung zat besi (fe) protein nabati dan hewani, buah-buahan dan sayuran hijau yang banyak mengandung vitamin $\mathrm{C}$ yang dapat meningkatkan absorpsi zat besi (Fe). Selain itu, pencegahan anemia dapat dilakukan dengan penambahan suplementasi tablet tambah darah. Setiap tablet untuk penanggulangan anemia gizi besi mengandung ferro sulfat $200 \mathrm{mg}$. Suplementasi tablet zat besi ( $\mathrm{Fe}$ ) yang harus diminum oleh ibu hamil paling sedikit 90 tablet selama masa kehamilan. Konsumsi tablet $\mathrm{Fe}$ ini tidak dianjurkan bersamaan dengan teh, susu, atau kopi karena dapat menurunkan penyerapan zat besi. Sedangkan untuk waktu konsumsi tablet tambah darah ( $\mathrm{Fe}$ ) dianjurkan setelah makan malam menjelang tidur dan lebih baik dibarengi dengan buah yang mengandung Vit C.(Fathonah,2016).

Pemilihan buah jambu biji sebagai cara untuk meningkatkan adsorbsi besi karena jambu biji merupakan sumber vitamin $C$ yang tinggi dibandingkan dengan buah lainnya. Dalam setiap 100 gram buah jambu biji mengandung energy 49 kal, protein 0,90 gram, lemak 0,30 gram, karbohidrat 12,20 gram, kalsium $14 \mathrm{mg}$, fosfor 28 $\mathrm{mg}$, serat 5,6 gram, vitamin A 4,0 RE, Vitamin B1 dan B2 $0,05 \mathrm{mg}$, zat besi $1,10 \mathrm{mg}$ dan vitamin $C 87$ $\mathrm{mg}$. Terdapat beberapa manfaat utama vitamin $\mathrm{C}$ yang sangat baik untu tubuh, diantaranya yaitu untuk pembentukan kolagen dalam jaringan pengikat, meningkatkan absorbsi besi untuk pembentukan hemoglobin dalam darah, mendorong konversi asam folat dan mempengaruhi Sintesis kolerterol serta sebagai antioksidan dalam tubuh. (Cahyono, 2010).

Dari sebuah penelitian yang dilakukan oleh Yusnaini mahasiswa Program Pascasarjana UNDIP pada tahun 2014 diketahui bahwa memberikan intervensi berupa pemberian tablet $\mathrm{Fe}$ dan jus jambu biji dapat meningkatkan kadar $\mathrm{Hb}$ pada ibu hamil karena jambu biji mengandung vitamin $\mathrm{C}$ yang dapat membantu penyerapan zat besi pada tablet Fe yang diberikan untuk ibu hamil sehingga kadar $\mathrm{Hb}$ ibu hamil dapat meningkat.

Berdasarkan hasil pre survey yang peneliti lakukan di BPM Okdiah Betty,Amd.Keb Kec.Trimurjo Kab.Lampung Tengah pada bulan Januari 2021 terdapat 59 ibu hamil trimester I-III yang melakukan kunjungan ANC pada bulan Desemder 2020 hingga Januari 2021.

Berdasarkan latar belakang diatas, maka peneliti ingin melakukan penelitian tentang "Pengaruh Konsumsi Jambu Biji Terhadap Kadar HB Pada Ibu Hamil Anemia di BPM Okdiah Betty Kecamatan Trimurjo Kabupaten Lampung Tengah".

\section{METODOLOGI PENELITIAN}

Dalam penelitian ini menggunakan jenis penelitian kuantitatif, jenis penelitian ini merupakan jenis penlitian menganalisis pengaruh jambu biji terhadap kadar $\mathrm{Hb}$ ibu hamil yang 
mengklasifikasikan suatu data dan pengambilan data yang berhubungan dengan angka-angka baik yang diperoleh dari hasil pengukuran maupun dari nilai suatu data yang diperoleh. (Notoatmodjo,2012).

Penelitian ini dilakukan di BPM Okdiah Betty Kecamatan Trimurjo Kabupaten Lampung Tengah. Penelitian ini dilakukan pada tanggal 18 Juni - 01 Agustus 2021.

Populasi adalah keseluruhan objek penelitian atau keseluruhan objek yang diteliti. (Notoatmodjo,2018). Populasi pada penelitian ini yaitu seluruh ibu hamil yang melakukan Antenatal Care (ANC) di BPM Okdiah Betty Kec. Trimurjo Kab. Lampung Tengan sejak bulan desember 2020 sampai dengan januari 2021 yaitu sebanyak 59 orang pada Desember 2020 hingga Januari 2021.

Sampel adalah objek penelitian yang dianggap mewakili seluruh populasi. (Notoatmodjo,2018). Sampel pada penelitian ini ibu hamil yang melakukan Antenatal Care (ANC) di BPM Okdiah Betty, Amd.Keb Kec.Trimurjo Kab. Lampung Tengah berdasarkan kriteria inklusi dan eksklusi didapatkan sebanyak 30 orang, dimana 15 orang sebagai kelompok intervensi diberikan jambu biji dan tablet Fe dan 15 orang sebagai kelompok kontrol diberikan tablet Fe.

\section{HASIL DAN PEMBAHASAN \\ Karakteristik Responden}

Berdasarkan table terlihat bahwa dari 30 $(100 \%)$ responden pada kelompok intervensi dan kelompok kontrol, pada kelompok intervensi terdapat 4 orang $(27 \%)$ yang beresiko, 11 orang (73\%) tidak beresiko. Sedangkan pada kelompok kontrol 15 orang $(100 \%)$ tidak beresiko. Selain itu terdapat $9(60 \%)$ orang yang merupakan kehamilan primipara dan $6(40 \%)$ orang kehamilan multipara pada masing-masing kelompok.

Tabel 1.

Karakteristik Responden Berdasarkan Usia dan Paritas

\begin{tabular}{lcccc}
\hline \multirow{2}{*}{ Karakteristik } & \multicolumn{2}{c}{ Kelompomk Intervensi } & \multicolumn{2}{c}{ Kelompok Kontrol } \\
\cline { 2 - 5 } & Frekuensi & Persentase (\%) & Frekuensi & Persentase (\%) \\
\hline Usia Responden & & & & \\
Beresiko (<20 dan >35 tahun) & 4 & 27 & 0 & 0 \\
Tidak Beresiko (20-35 tahun) & 11 & 73 & 15 & 100 \\
$\begin{array}{l}\text { Paritas Responden } \\
\text { Primipara }\end{array}$ & 9 & 60 & 9 & 60 \\
Multipara & 6 & 40 & 6 & 40 \\
\hline \multicolumn{1}{c}{ Total } & 15 & 100,0 & 15 & 100,0 \\
\hline
\end{tabular}

Tabel 2.

Hasil Uji Normalitas Variabel Kelompok Intervensi dan Kelompok Kontrol Test of Normallity

\begin{tabular}{lc}
\hline \multicolumn{1}{c}{ Nilai Skor Test } & Nilai Shapiro Wilk \\
\hline Pretest Kelompok Intervensi & 0,004 \\
Posttest Kelompok Intervensi & 0,000 \\
Pretest Kelompok Kontrol & 0,274 \\
Posttest Kelompok Kontrol & 0,030 \\
\hline
\end{tabular}

Berdasarkan tabel di atas dapat dilihat bahwa nilai Shapiro Wilk yaitu 0,004 untuk nilai pretest kelompok intervensi dan 0,000 untuk nilai posttest kelompok intervensi, nilai pretest untuk kelompok kontrol sebesar 0,275 dan nilai posttest kelompok kontrol 0,030 yang artinya sebagian besar data memiliki $P<0,05$. Dengan demikian dapat diambil kesimpulan bahwa data kedua variabel dalam penelitian ini berdistribusi tidak normal. Sehingga dilakukan Uji Mann Whitney.

\section{Analisis Univariat}

Berdasarkan tabel 3 dibawah dapat diketahui bahwa dari 15 responden penelitian, diperoleh hasil nilai mean atau rata-rata kadar hemoglobin sebelum diberikan intervensi sebesar 10,53 gr/dl dengan hasil kadar hemoglobin terendah atau minimal yaitu sebesar 9,00 $\mathrm{gr} / \mathrm{dl}$ dan hasil kadar hemoglobin teringgi atau maximal sebesar $11,40 \mathrm{gr} / \mathrm{dl}$. 
Tabel 3.

Rata-rata kadar hemoglobin sebelum konsumsi jambu biji dan tablet Fe Pada Ibu hamil di BPM Okdiah Betty, Amd.Keb Kec.Trimurjo Kab.Lampung Tengah

\begin{tabular}{lcccccc}
\hline \multicolumn{1}{c}{ Variabel } & N & Mean & Median & SD & Min & Max \\
\hline $\begin{array}{l}\text { Hasil Pengukuran Kadar Hemoglobin Sebelum } \\
\text { Konsumsi Jus Jambu Biji dan Tablet Fe }\end{array}$ & 15 & 10,53 & 11,00 & 0,73160 & 9,00 & 11,40 \\
\hline
\end{tabular}

Tabel 4.

Rata-rata kadar hemoglobin setelah konsumsi jambu biji dan tablet Fe Pada lbu hamil di BPM Okdiah Betty, Amd.Keb Kec.Trimurjo Kab.Lampung Tengah

\begin{tabular}{lcccccc}
\hline \multicolumn{1}{c}{ Variabel } & N & Mean & Median & SD & Min & Max \\
\hline $\begin{array}{l}\text { Hasil Pengukuran Kadar Hemoglobin Setelah } \\
\text { Konsumsi Jus Jambu Biji dan Tablet Fe }\end{array}$ & 15 & 11,58 & 11,50 & 0,11464 & 11,50 & 11,80 \\
\hline
\end{tabular}

Berdasarkan tabel 4 diatas dapat diketahui bahwa dari 15 responden penelitian, diperoleh hasil nilai mean atau rata-rata kadar hemoglobin setelah diberikan intervensi sebesar $11,58 \mathrm{gr} / \mathrm{dl}$ dengan hasil kadar hemoglobin terendah atau minimal yaitu sebesar $11,50 \mathrm{gr} / \mathrm{dl}$ dan hasil kadar hemoglobin teringgi atau maximal sebesar $11,80 \mathrm{gr} / \mathrm{dl}$.

Tabel 5.

Rata-rata kadar hemoglobin sebelum konsumsi tablet Fe Pada Ibu hamil di BPM Okdiah Betty, Amd.Keb Kec.Trimurjo Kab.Lampung Tengah

\begin{tabular}{lll|c|c|l|c|c|c}
\hline \multicolumn{3}{c|}{ Variabel } & N & Mean & $\begin{array}{l}\text { Medi } \\
\text { an }\end{array}$ & SD & Min & Max \\
\hline $\begin{array}{l}\text { Hasil Pengukuran Kadar Hemoglobin Sebelum } \\
\text { Konsumsi Tablet Fe }\end{array}$ & 15 & 11,02 & 11,00 & 0,32338 & 10,40 & 11,70 \\
\hline
\end{tabular}

Berdasarkan tabel diatas dapat diketahui bahwa dari 15 responden penelitian, diperoleh hasil mean atau rata-rata kadar hemoglobin setelah diberikan intervensi sebesar $11,02 \mathrm{gr} / \mathrm{dl}$ dengan nilai hasil kadar hemoglobin terendah atau minimal yaitu sebesar $10,40 \mathrm{gr} / \mathrm{dl}$ dan hasil kadar hemoglobin teringgi atau maximal sebesar $11,70 \mathrm{gr} / \mathrm{dl}$.

Tabel 6.

Rata-rata kadar hemoglobin setelah konsumsi tablet Fe Pada Ibu hamil di BPM Okdiah Betty, Amd.Keb Kec.Trimurjo Kab.Lampung Tengah

\begin{tabular}{|c|c|c|c|c|c|c|}
\hline Variabel & $\mathbf{N}$ & Mean & $\begin{array}{l}\text { Medi } \\
\text { an }\end{array}$ & SD & Min & Max \\
\hline $\begin{array}{l}\text { Hasil Pengukuran Kadar Hemoglobin Setelah Konsumsi } \\
\text { Tablet Fe }\end{array}$ & 15 & 11,42 & 11,40 & 0,9612 & 11,30 & 11,60 \\
\hline
\end{tabular}

Berdasarkan tabel diatas dapat diketahui bahwa dari 15 responden penelitian, diperoleh hasil nilai mean atau rata-rata kadar hemoglobin setelah diberikan intervensi sebesar $11,42 \mathrm{gr} / \mathrm{dl}$ dengan hasil kadar hemoglobin terendah atau minimal yaitu sebesar 11,30 gr/dl dan hasil kadar hemoglobin teringgi atau maximal sebesar $11,60 \mathrm{gr} / \mathrm{dl}$.

\section{Analisis Bivariat}

Berdasarkan tabel diatas dapat diketahui hasil Mann Whitney didapat nilai Asymp. Sig atau $p$ value $0,000<a(0,05)$ artinya $\mathrm{Ho}$ ditolak dan $\mathrm{Ha}$ diterima, yang berarti ada Pengaruh Konsumsi Jambu Biji Terhadap Kadar Hb Pada Ibu Hamil Anemia Di BPM Okdiah Betty Kecamatan Trimurjo Kabupaten Lampung Tengah. 
Tabel 7.

Perbandingan Konsumsi Jambu Biji dan Tablet Fe dengan Tablet Fe Terhadap Kadar Hb Pada lbu Hamil Anemia Di BPM Okdiah Betty Kecamatan Trimurjo Kabupaten Lampung Tengah

\begin{tabular}{lcccc}
\hline Hasil Pengukuran Hemoglobin & N & Mean Rank & Sum of Ranks & Asymp Sig (2-Tailed) \\
\hline Kelompok Intervensi & 15 & 23,00 & 345,00 & 0,000 \\
Kelompok Kontrol & 15 & 21,13 & 317,00 & 0,000 \\
\hline
\end{tabular}

\section{PEMBAHASAN}

\section{Analisis Univariat}

Rata-rata kadar hemoglobin sebelum konsumsi jambu biji dan tablet Fe Pada Ibu hamil di BPM Okdiah Betty, Amd.Keb Kec.Trimurjo Kab.Lampung Tengah

Berdasarkan hasil penelitian di BPM Okdiah Betty, Amd.Keb Kec. Trimurjo Kab. Lampung Tengah dapat diketahui bahwa nilai mean atau ratarata kadar hemoglobin sebelum diberikan intervensi sebesar 10,533 gr/dl, nilai minimal 9,00 gr/dl, dan nilai maximal sebesar $11,40 \mathrm{gr} / \mathrm{dl}$.

Hasil penelitian ini sejalan dengan penelitian yang telah dilakukan oleh Yusnaini mahasiswa Program Pascasarjana UNDIP pada tahun 2014 tentang studi kasus ibu hamil di wilayah kerja Puskesmas Kecamatan Indrapuri Kabupaten Aceh Besar Provinsi Aceh yang sudah melakukan studi dan membuktikan adanya perubahan kadar hemoglobin pada ibu hamil anemia yang diberikan intervensi suplementasi tablet Fe dan jus jambu biji dengan hasil penelitian didapatkan ada pengaruh pemberian jambu biji terhadap kadar hemoglobin pada ibu hamil $p$ value $0,014<0,05$.

Hal ini sesuai dengan teori bahwa anemia adalah kekurangan kadar hemoglobin $(\mathrm{Hb})$ dalam darah yang disebabkan karena kekurangan zat gizi. Anemia gizi besi adalah anemia yang disebabkan karena kekurangan zat gizi besi ( $\mathrm{Fe})$ dalam darah. (Fathonah, 2016).

Konsentrasi hemoglobin normal pada wanita hamil berebda dengan wanita tidak hamil. Hal ini disebabkan karena pada kehamilan terjadi proses hemodilusi atau pengenceran darah, yaitu peningkatan volume plasma dalam proporsi yag lebih besar jika dibandingkan dengan peningkatam eritrosit. Hemodilusi berfungsi agar suplai darah untuk pembesaran uterus terpenuhi, melindungi ibu dan janin dari efek negative kehilangan darah saat proses melahirkan. (Manuaba, 2010).

Menurut pendapat peneliti anemia adalah kondisi dimana kadar $\mathrm{Hb}$ ibu dibawah normal $<<$ $11 \mathrm{gr} / \mathrm{dl})$. Kandungan $\mathrm{Hb}$ yang rendah dapat mengindikasikan anemia, dengan gejala yang berupa lemah, kurang nafsu makan, kurang energi, konsentrasi menurun, sakit kepala, mudah terinfeksi penyakit , mata berkunang-kunang, selain itu kelopak mata, bibir, dan kuku tampak pucat. Penyebab tersering anemia adalah defisiensi besi dan kehilangan darah dalam jumlah besar. Terkadang keduanya saling berkaitan erat, karena pengeluaran darah yang berlebihan disertai hilangnya besi hemoglobin dan terkurasnya simpanan besi pada suatu kehamilan dapat menjadi penyebab penting anemia defisiensi besi pada kehamilan.

Rata-rata kadar hemoglobin setelah konsumsi jambu biji dan tablet Fe Pada Ibu hamil di BPM Okdiah Betty, Amd.Keb Kec.Trimurjo Kab.Lampung Tengah

Berdasarkan hasil penelitian di BPM Okdiah Betty, Amd.Keb Kec. Trimurjo Kab. Lampung Tengah dapat diketahui bahwa nilai mean atau ratarata kadar hemoglobin setelah diberikan intervensi sebesar 11,580 gr/dl, nilai minimal 11,50 gr/dl, dan nilai maximal sebesar $11,80 \mathrm{gr} / \mathrm{dl}$.

Hasil penelitian ini sejalan dengan penelitian yang telah dilakukan oleh Yusnaini mahasiswa Program Pascasarjana UNDIP pada tahun 2014 tentang studi kasus ibu hamil di wilayah kerja Puskesmas Kecamatan Indrapuri Kabupaten Aceh Besar Provinsi Aceh yang sudah melakukan studi dan membuktikan adanya perubahan kadar hemoglobin pada ibu hamil anemia yang diberikan intervensi suplementasi tablet $\mathrm{Fe}$ dan jus jambu biji dengan hasil penelitian didapatkan ada pengaruh pemberian jambu biji terhadap kadar hemoglobin pada ibu hamil $p$ value $0,014<0,05$.

Pada penelitian ini didapat nilai kadar $\mathrm{Hb}$ setelah diberikan intervensi menggunakan jus jambu biji mengalami peningkatan dengan selisih skor $0,4-2,5 \mathrm{gr} / \mathrm{dl}$ dalam 14 hari intervensi. Hal ini dikarenakan keteraturan ibu saat mengonsumsi jus jambu biji, Jambu biji sebagai bahan makanan mengandung nutrisi yang lengkap. Jambu biji merupakan sumber vitamin $C$ yang tinggi dibandingkan dengan buah lainnya. Dalam setiap 100 gram buah jambu biji mengandung energy 49 kal, protein 0,90 gram, lemak 0,30 gram, karbohidrat 12,20 gram, kalsium $14 \mathrm{mg}$, fosfor 28 $\mathrm{mg}$, serat 5,6 gram, vitamin A 4,0 RE, Vitamin B1 dan B2 $0,05 \mathrm{mg}$, zat besi $1,10 \mathrm{mg}$ dan vitamin $\mathrm{C} 87$ mg. Terdapat beberapa manfaat utama vitamin $\mathrm{C}$ 
yang sangat baik untu tubuh, diantaranya yaitu untuk pembentukan kolagen dalam jaringan pengikat, meningkatkan absorbsi besi untuk pembentukan hemoglobin dalam darah, mendorong konversi asam folat dan mempengaruhi Sintesis kolerterol serta sebagai antioksidan dalam tubuh. Peranan vitamin $C$ dalam proses penyerapan zat besi $(\mathrm{Fe})$ yaitu untuk membantu mereduksi besi ferri $\left(\mathrm{Fe}^{3+}\right)$ menjadi ferro $\left(\mathrm{Fe}^{2+}\right)$ dalam usus halus shingga mudah terabsorbsi, proses reduksi tersebut akan semakin besar bila $\mathrm{pH}$ di dalam lambung semakin asam. Vitamin C dapat menambah keasaman sehingga dapat meingkatkan penyerapan zat besi. Sehingga kadar hemoglobin dalam darah dapat meningkat. (Cahyono,2010).

Rata-rata kadar hemoglobin sebelum konsumsi tablet Fe Pada Ibu hamil di BPM Okdiah Betty, Amd.Keb Kec.Trimurjo Kab.Lampung Tengah

Berdasarkan hasil penelitian di BPM Okdiah Betty, Amd.Keb Kec. Trimurjo Kab. Lampung Tengah dapat diketahui bahwa nilai mean atau ratarata kadar hemoglobin sebelum konsumsi tablet $\mathrm{Fe}$ sebesar 11,02 gr/dl, nilai minimal 11,04 gr/dl, dan nilai maximal sebesar $11,70 \mathrm{gr} / \mathrm{dl}$.

Hal ini sesuai dengan teori bahwa anemia adalah kekurangan kadar hemoglobin $(\mathrm{Hb})$ dalam darah yang disebabkan karena kekurangan zat gizi. Anemia gizi besi adalah anemia yang disebabkan karena kekurangan zat gizi besi ( $\mathrm{Fe}$ ) dalam darah. (Fathonah, 2016).

Pada kehamilan kebutuhan oksigen akan lebih tinggi sehingga memicu peningkatan produksi eritropeotin. Akibatnya volume plasma bertambah dan sel darah merah meningkat. Namun peningkatan volume plasma terjadi dalam proporsi yang lebih besar jika dibandingkan dengan eritrosit sehingga terjadi penurunan konsentrasi hemoglobin akibat hemodilusi. (Manuaba, 2010).

Konsentrasi hemoglobin normal pada wanita hamil berebda dengan wanita tidak hamil. Hal ini disebabkan karena pada kehamilan terjadi proses hemodilusi atau pengenceran darah, yaitu peningkatan volume plasma dalam proporsi yag lebih besar jika dibandingkan dengan peningkatam eritrosit. Hemodilusi berfungsi agar suplai darah untuk pembesaran uterus terpenuhi, melindungi ibu dan janin dari efek negative kehilangan darah saat proses melahirkan. (Manuaba, 2010).

Pencegahan anemia dapat dilakukan dengan penambahan suplementasi tablet tambah darah dan asam folat. Setiap tablet untuk penanggulangan anemia gizi besi mengandung ferro sulfat $200 \mathrm{mg}$. Suplementasi tablet zat besi (Fe) yang harus diminum oleh ibu hamil paling sedikit 90 tablet selama masa kehamilan. (Proverawati, 2018).

Rata-rata kadar hemoglobin setelah konsumsi tablet Fe Pada Ibu hamil di BPM Okdiah Betty, Amd.Keb Kec.Trimurjo Kab.Lampung Tengah

Berdasarkan hasil penelitian di BPM Okdiah Betty, Amd.Keb Kec. Trimurjo Kab. Lampung Tengah dapat diketahui bahwa nilai mean atau ratarata kadar hemoglobin setelah konsumsi tablet $\mathrm{Fe}$ sebesar $11,42 \mathrm{gr} / \mathrm{dl}$, nilai minimal $11,30 \mathrm{gr} / \mathrm{dl}$, dan nilai maximal sebesar $11,60 \mathrm{gr} / \mathrm{dl}$.

Dari penelitian ini didapatkan bahwa nilai kadar $\mathrm{Hb}$ pada kelompok kontrol meningkat sebanyak 0,1 - 0,9 gr/dl dalam 14 hari. Hal tersebut dikarenakan pada saat dilakukan penelitian responden tetap mengonsumsi makanan dan minuman yang dapat menghambat absorbsi zat besi seperti teh dan kopi.

\section{Analisis Bivariat}

Pengaruh Konsumsi Jambu Biji dan Tablet Fe dengan Tablet Fe Terhadap Kadar Hb Pada Ibu Hamil Anemia Di BPM Okdiah Betty Kecamatan Trimurjo Kabupaten Lampung Tengah

Berdasarkan hasil penelitian di BPM Okdiah Betty, Amd.Keb Kec. Trimurjo Kab. Lampung Tengah diketahui bahwa nilai mean atau rata-rata kadar hemoglobin sebelum diberikan intervensi sebesar 10,533 $\mathrm{gr} / \mathrm{dl}$ dan setelah diberikan intervensi nilai kadar $\mathrm{Hb} 11,580 \mathrm{gr} / \mathrm{dl}$.

Sedangkan berdasarkan hasil penelitian di BPM Okdiah Betty, Amd.Keb Kec. Trimurjo Kab. Lampung Tengah diketahui bahwa nilai mean atau rata-rata kadar hemoglobin sebelum konsumsi tablet Fe sebesar 11,02 gr/dl dan setelah konsumsi tablet fe adalah $11,42 \mathrm{gr} / \mathrm{dl}$.

Hasil uji statistik menggunakan uji Mann Whitney didapat $p$ value $=0,000<a(0,05)$, artinya Ho ditolak dan Ha diterima, yang berarti ada pengaruh konsumsi jambu biji terhadap kadar $\mathrm{Hb}$ pada ibu hamil anemia di BPM Okdiah Betty Kecamatan Trimurjo Kabupaten Lampung Tengah.

Hasil penelitian ini sejalan dengan penelitian yang telah dilakukan oleh Yusnaini mahasiswa Program Pascasarjana UNDIP pada tahun 2014 tentang studi kasus ibu hamil di wilayah kerja Puskesmas Kecamatan Indrapuri Kabupaten Aceh Besar Provinsi Aceh yang sudah melakukan studi dan membuktikan adanya perubahan kadar hemoglobin pada ibu hamil anemia yang diberikan intervensi suplementasi tablet Fe dan jus jambu biji dengan hasil penelitian didapatkan ada pengaruh pemberian jambu biji terhadap kadar hemoglobin pada ibu hamil $p$ value $0,014<0,05$. 


\section{JKM (Jurnal Kebidanan Malahayati),Vol 7,No.4.Oktober 2021, ISSN (Print) 2476-8944 ISSN (Online) 2579-762X, Hal 793-800}

Hasil penelitian ini juga sejalan dengan penelitian tentang jambu biji yang dilakukan pada tahun 2018 oleh Siti Rahmah safitri yaitu tentang efektivitas jus jambu biji terhadap kadar hemoglobin ibu hamil trimester III di Klinik Pratama Rahma Desa Paya Tusam Kec.Way Umpu Kab.Langkat yang terbukti memberikan pengaruh terhadap peningkatan hemoglobin ibu hamil. Dari penelitiannya, didapatkan peningkatan kadar hemoglobin rata-rata sebesar $0,40 \mathrm{gr} / \mathrm{dL}$.

Hasil penelitian ini juga sejalan dengan penelitian yang juga dilakukan oleh Megawati, mahasiswi Politeknik Kesehatan Kalimantan Timur tentang pengaruh jus jambu biji merah dan kurma terhadap peningkatan kadar hemoglobin pada ibu hamil trimester II di Praktik Mandiri Bidan Indrawati tahun 2020. Dari penelitian ini didapatkan peningkatan rata-rata kadar $\mathrm{Hb}$ sebesar $12,23 \mathrm{gr} / \mathrm{dL}$ setelah intervensi yang dilakukan pada ibu hamil anemia tersebut.

Dari ketiga penelitian diatas, telah terbukti bahwa jambu biji dapat membantu meningkatkan kadar hemoglobin pada ibu hamil anemia. Hal ini dikarenakan kandungan vitamin $\mathrm{C}$ yang ada di dalam jambu biji yang dapat meningkatkan kualitas absorbsi zat besi dalam tubuh sehingga kadar hemoglobin ibu hamil anemia.

Hal ini juga sejalan dengan teori bahwa, pencegahan anemia dapat dilakukan dengan penambahan suplementasi tablet tambah darah dan asam folat. Setiap tablet untuk penanggulangan anemia gizi besi mengandung ferro sulfat $200 \mathrm{mg}$. Suplementasi tablet zat besi $(\mathrm{Fe})$ yang harus diminum oleh ibu hamil paling sedikit 90 tablet selama masa kehamilanhwa, (Proverawati, 2018).

Nutrisi yang terbaik untuk mencegah terjadinya anemia jika sedang hamil adalah makan makanan yang tinggi kandungan zat besi (seperti sayuran berdaun hijau, daging, sereal, telur, dan kacang tanah). (Proverawati, 2018).

Penting untuk memperhatikan apa yang diminum bersamaan dengan tablet zat besi. Mengonsumsi makanan yang kaya vitamin $C$ bersama dengan zat besi akan meningkatkan penyerapan besi. Namun, mengambil minuman berkafein bersama dengan makanan tinggi zat besi akan mengurangi jumlah besi yang diserap tubuh. Termasuk teh, susu, atau kopi karena dapat menurunkan penyerapan zat besi. Sedangkan untuk waktu konsumsi tablet tambah darah (Fe) dianjurkan setelah makan malam menjelang tidur dan lebih baik dibarengi dengan buah yang mengandung Vit C.(Proverawati, 2018).

Jambu biji (Psidium Guajava L) adalah buah yang memiliki kulit tipis dan permukaan halus sampai kasar. Buah yang telah masak dagingnya lunak, sedangkan yang belum masak dagingnya keras dan renyah. Buah memiliki rasa manis, kurang manis, dan hambar, tergantung dari varietas dan teknik/cara pembudidayanya.

Jambu biji sebagai bahan makanan mengandung nutrisi yang lengkap. Jambu biji merupakan sumber vitamin $C$ yang tinggi dibandingkan dengan buah lainnya.

Dalam setiap 100 gram buah jambu biji mengandung energy $49 \mathrm{kal}$, protein 0,90 gram, lemak 0,30 gram, karbohidrat 12,20 gram, kalsium $14 \mathrm{mg}$, fosfor $28 \mathrm{mg}$, serat 5,6 gram, vitamin A 4,0 $\mathrm{RE}$, Vitamin B1 dan B2 0,05 mg, zat besi $1,10 \mathrm{mg}$ dan vitamin $\mathrm{C} 87 \mathrm{mg}$.

Terdapat beberapa manfaat utama vitamin $\mathrm{C}$ yang sangat baik untu tubuh, diantaranya yaitu untuk pembentukan kolagen dalam jaringan pengikat, meningkatkan absorbsi besi untuk pembentukan hemoglobin dalam darah, mendorong konversi asam folat dan mempengaruhi Sintesis kolerterol serta sebagai antioksidan dalam tubuh. Peranan vitamin $C$ dalam proses penyerapan zat besi (Fe) yaitu untuk membantu mereduksi besi ferri $\left(\mathrm{Fe}^{3+}\right)$ menjadi ferro $\left(\mathrm{Fe}^{2+}\right)$ dalam usus halus shingga mudah terabsorbsi, proses reduksi tersebut akan semakin besar bila $\mathrm{pH}$ di dalam lambung semakin asam. Vitamin $\mathrm{C}$ dapat menambah keasaman sehingga dapat meingkatkan penyerapan zat besi. Sehingga kadar hemoglobin dalam darah dapat meningkat. (Cahyono,2010).

Tidak hanya kaya akan rasa dan aroma khas dari eugenol yang terkandung di dalamnya jambu biji juga kaya kandungan vitamin $\mathrm{C}$. Kandungan vitamin $C$ pada jambu biji setara dengan enam kali kandungan vitamin C pada buah jeruk, 10 kali kandungan vitamin C pada papaya, 17 kali kandungan vitamin $\mathrm{C}$ pada jambu air, dan 30 kali kandungan vitamin $\mathrm{C}$ pada pisang. Sebagian besar vitamin $\mathrm{C}$ jambu biji terkonsentrasi pada kulit dan daging bagian luarnya yang lunak dan tebal. Oleh karena itu, sebaiknya makanlah jambu biji bersama dengan kulitnya. Kandungan vitamin $C$ pada jambu biji mencapai puncaknya menjelang matang.

Banyak cara untuk mengonsumsi jambu biji, selain dapat langsung dikonsumsi secara langssung jambu biji juga dapat dibuat minuman seperti jus jambu biji untuk menghindari rasa bosan dalam mengonsumsinya. Dengan memakan satu buah jambu biji per hari (estimasi berat jambu biji 150$250 \mathrm{~g}$ ), dapat mencukupi kebutuhan harian untuk vitamin $\mathrm{C}$, vitamin $\mathrm{A}$, niacin, asam folat, serta fosfor. (Hadiati, 2015).

Menurut pendapat peneliti berdasarkan hasil penelitian dimana hasil kadar hemoglobin pada ibu 
hamil tersebut berbeda-beda. Hal terseut dikarenakan oleh beberapa faktor seperti usia dan paritas ibu dimana ibu yang usianya lebih tua ( $>35$ tahun) memiliki kadar hemoglobin yang lebih rendah dibandingkan ibu yang usianya lebih muda (20 - <35 tahun). Sedangkan pada usia ibu, ibu hamil pada usia terlalu muda tidak atau belum siap untuk memperhatikan lingkungan yang diperlukan untuk pertumbuhan janin, disamping itu akan terjadi kompetisi makanan antara janin dan ibunya sendiri yang masih dalam pertumbuhan dan adanya pertumbuhan hormonal yang terjadi selama masa kehamilan. Sedangkan ibu hamil yang usianya lebih tua cenderung mengalami anemia, hal ini disebabkan karena pengaruh turunnya cadangan zat besi dalam tubuh akibat masa fertilisasi. selain itu perbedaan kadar hemoglobin pada ibu hamil dikarenakan juga oleh seperti kebiasaan ibu hamil dalam memenuhi nutrisi ibu hamil yang didapatkan dari makanan yang mereka makan setiap harinya.

Hal lain didapatkan pada hasil penelitian ini yaitu kenaikan kadar hemoglobin pada ibu hamil tersebut berbeda-beda hal tersebut dikarenakan pada saat dilakukan penelitian responden tetap mengonsumsi makanan yang dapat menghambat absorbsi zat besi seperti teh dan kopi.

\section{SIMPULAN}

Diketahui Pengaruh Konsumsi Jambu Biji dan Tablet Fe dengan Tablet Fe Terhadap Kadar Hemoglobin Pada Ibu hamil anemia di BPM Okdiah Betty,Amd.Keb Kec.Trimurjo Kab.Lampung Tengah, uji Mann Withney ( $p$ value 0,000 < a 0,05).

\section{SARAN}

Sebagai bahan informasi bagi bidan dalam memberikan promosi kesehatan dan pengetahuan tentang manfaat jambu biji untuk mencegah terjadinya anemia melalui banner atau spanduk yang terpasang di tempat praktik bidan

\section{DAFTAR PUSTAKA}

Agustina, Rina. 2020. Pengaruh Konsumsi Jus Jambu Biji Merah Terhadap Peningkatan Kadar Hemoglobin Pada Ibu Hamil Di Puskesmas Saketi.Pandeglang : Asian Research Midwifery and Basic Science Journal.

Ani, Luh Seri. 2010. Anemia Defisiensi Besi Masa Prahamil \& Hamil. Jakarta : EGC.
Astuti, Sri dkk. 2016. Asuhan Ibu Dalam Masa Kehamilan. Jakarta : Erlangga.

Cahyono, Bambang. 2010. Sukses Budi Daya Jambu Biji Di Pekarangan \&Perkebunan.Yogyakarta:Lily Publisher.

Dahlan, M.Sopiyudin. 2014. Statistik Untuk Kedokteran dan Kesehatan Deskriptif, Bivariat, dan Multivariat. Jakarta: Epidemiologi Indonesia.

Fathonah, Siti. 2016. Gizi \& Kesehatan Untuk Ibu Hamil. Jakarta : Erlangga.

Fitriani, Yulia. 2017. Pengaruh Pemberian Jus Jambu Biji Terhadap Kadar HB Pada Ibu Hamil Trimester III di Polindes Krebet Kabupaten Bululawang Kabupaten Malang. Malang : Jurnal EDU Midwifery.

Hadiati, Sri. 2015. Bertanam Jambu Biji Di Pekarangan. Jakarta : Agriflo.

Khomsatun, Siti. 2020. Pengaruh Konsumsi Ubi Jalar Terhadap Kadar Hemoglobin Ibu Hamil Trimester III Di Puskesmas Branti Kabupaten Lampung Selatan Tahun 2020.Bandar Lampung : Universitas Malahayati.

Manuaba, dkk. 2010. IImu Kebidanan, Penyakit Kandungan, dan KB. Jakarta : EGC.

Megawati. 2020. Pengaruh Pemberian Jus Jambu Biji Merah dan Kurma Terhadap Peningkatan Kadar Henoglobin Pada Ibu Hamil Trimester III di Praktik Mandiri Bidan Indrawaty Tahun 2020 Kalimantan Timur : Poltekkes Kaltim.

Notoatmodjo, Soekidjo. 2018. Metodologi Penelitian Kesehatan. Jakarta : Rineka Cipta.

Proverawati, Atikah. 2018. Anemia Dan Anemia Kehamilan. Yogyakarta : Nuha Medika.

Ramayulis, Rita. 2016. Super Jus. Jakarta : Penebar Plus.

Ratnawati, Ana. 2017. Asuhan Keperawatan Maternitas. Yogyakarta : Pustaka Baru Press.

Sahfitri, Riti Rahmah. 2018. Efektivitas Tablet Fe dengan Tablet Fe Disertai Jus Jambu Biji Terhadap Kadar Hemoglobin Ibu Hamil TM III di Klinik Pratama Rahma Kec.Wampu Kab.Langkat. Medan : Poltekkes Kemenkes Medan.

Sugiyono, 2019. Statistika Untuk Penelitian. Bandung : Alfabeta.

Pratikna, Ahmad Watik. 2013. Dasar-dasar Metodologi Penelitian Kedokteran dan Kesehatan. Jakarta : Rajawali Pers. 